\title{
The Readiness of Applying M-Learning among Saudi Arabian Students at Higher Education
}

\author{
http://dx.doi.org/10.3991/ijim.v9i3.4423 \\ Sulaiman Almutairy, Trevor Davies, Yota Dimitriadi \\ University of Reading, United Kingdom
}

\begin{abstract}
This paper presents study investigating the extent to which Saudi students understand and are familiar with mobile learning. It investigates students' use of handheld devices and considers the daily activities for which they could be used while also evaluating m-learning in Saudi Arabia - a topic that has not yet received adequate attention from researchers. Initial data was acquired through a questionnaire carried out among 131 Saudi students at UK universities in July 2013. The study confirmed that students' are confident using mobile devices in their daily lives and that they would welcome more opportunities of mobile learning. The findings reinforce the fact that higher education policy makers in Saudi Arabia need to consider the possibility of creating mobile learning environments at academic institutions.
\end{abstract}

Index Terms-M-learning, mobile technology

\section{INTRODUCTION}

The process of learning and accessing information has undergone rapid changes in the past decade. A global technology revolution is taking place, resulting in a transition from desktop computing to widespread use of mobile technology. Technology is changing the way people work, learn, conduct business, interact with one another and access information [1]. The learning process is no longer reliant on traditional teaching methods, but has expanded to include new technologies and new forms of learning, such as mobile learning (m-learning). Mobile technologies offer opportunities to deliver new and interesting methods of learning, both outside and inside the classroom.

M-learning involves the ability to acquire information anywhere, at any time, using handheld devices such as mobile phones and Personal Digital Assistants (PDAs). M-learning is defined as:

Any sort of learning that happens when the learner is not at a fixed, predetermined location, or learning that happens when the learner takes advantage of the learning opportunities offered by mobile technologies (p. 6) [2].

New figures released in 2014 by the International Telecommunication Union (ITU) predict that the number of mobile-cellular subscriptions will reach 7 billion by the end of the year. Thus, by the end of 2014 there will be almost 3 billion Internet users, two-thirds of whom will be located in the developing world. The ICT Commission states that, by the end of 2013, in Saudi Arabia, which is a developing country, the number of mobile phone subscribers had almost reached 51 million. The majority of these connect to the Internet using a wireless connection, or via a $3 \mathrm{G}$ or $4 \mathrm{G}$ mobile phone network [3], [4].

\section{The SAUdi ARABIAN CONTEXT}

Saudi Arabia is currently experiencing a comprehensive developmental renaissance in various areas of life. The government has established an infrastructure that will ensure optimal use of information and communications technology in education. The average age of Saudi Arabians is now 25.3 years and the total population is $29,994,272$. The estimated number of graduates from public education institutions is 450,000 students, all of whom subsequently attempt to secure a place in one of the country's 25 public universities; thereby, creating a demand for places which cannot be met.

If an m-learning environment were adopted in higher education it could address the issue of large numbers of students applying to universities, particularly the new generation of students born after 1980 and who grew up in the digital age, so-called 'digital natives' [5].

In Saudi Arabia, higher education policy makers should also consider the possibility of applying an m-learning environment in academic institutions.

\section{REVIEW OF M-LEARNING IN SAUDI ARABIA}

It is necessary to establish a clear definition of $\mathrm{m}$ learning before undertaking a review of the literature regarding m-learning in the context of Saudi Arabia. As mentioned previously, m-learning can take place anytime, anywhere. M-learning is:

'the processes of coming to know through conversations across multiple contexts amongst people and personal interactive technologies' p.225, [6].

Many universities and institutions in Saudi Arabia have begun to implement facilities to support m-learning. For example, King Saud University has launched a new service offering users the opportunity to send text messages to the mobile phones of individuals or groups of students, directly from their PCs. These messages allow faculty managers, schools and administrative divisions to deliver timely and relevant information to their students [7].

In addition, a study conducted by Al-Fahad [8] concluded that wireless networks effectively facilitate access to resources at anytime from anywhere using handheld devices. Additionally, he asserted that SMS can be used effectively to support and improve student relationships.

However, m-learning in Saudi Arabia is still in the developmental stages [9]. The researchers found that over $75 \%$ of Saudi Arabian students surveyed expressed positive attitudes to m-learning, due to the flexibility of $\mathrm{m}$ learning methods, and their scope to improve communication among learners. 


\section{Methodology}

The research method adopted for a study refers to the means through which a researcher intends to gather data. A survey based methodology is commonly used to collect results obtained from interviews and questionnaires. This reflects a specific approach which seeks to establish the relationship between variables and influential factors and trends.

This study acquired initial data during two weeks in July 2013, using an online survey comprising 30 questions. This data collection phase took place at a UK university with 131 Saudi Arabian students. The questionnaire collected information to provide general information regarding Saudi students employment of handheld devices in different settings, and to explore Saudi Arabian students' readiness to engage in, and familiarise themselves with, m-learning. It also examined and measured the extent of Saudi Arabian students' acceptance of the notion of an mlearning environment being formally introduced by higher education institutions. The research took the form of a descriptive study. The questionnaire was divided into four sections namely: (1) demographic data; (2) personal attitudes; (3) definition of m-learning; and (4) opportunities. A five point Likert Scale was used to measure the responses to the main questions, ranging from: strongly disagree; disagree; agree; strongly agree and not sure.

As mentioned previously, there are currently 51 million mobile phone subscribers in Saudi Arabia and between 110,000 and 125,000 male and female Saudi students are studying abroad [10]. The majority of these are able to connect to the Internet. Thus, a survey is therefore an appropriate research tool for such a study.

\section{RESEARCH SAMPLE}

The participants in this research are Saudi Arabian higher education students studying in UK universities. The sample comprises higher education students of both genders, aged 18 to 45 years.

The quality of a piece of research not only stands or falls by the appropriateness of methodology and instrumentation, but also by the suitability of the sampling strategy that has been adopted. (p. 92) [11].

The sample was selected randomly, from different institutions and levels of study, in order to involve a wide range of Saudi Arabian higher education students, who use handheld devices for learning purposes.

Table 1 presents the distribution of the study sample according to demographic variables. It reveals that out of a sample of 131 students, 42 were female and 89 were male. It also reveals the age distribution of the sample with the majority being in the age group 18-33 years. In addition, the majority are educated to either Masters' or $\mathrm{PhD}$ level.

\section{FINDINGS}

This study initially aimed to investigate the extent of Saudi students' understanding of and their readiness to use the m-learning environment formally. It investigated the students' habits of use, preferred knowledge of handheld devices and the daily activities to which handheld devices can contribute.

Figure 1 reveals that Engineering, Education and Health Science are the three disciplines, which are most popular among Saudi Arabian students at universities around the UK.

All the Saudi students selected for this study had mobile phones. Of the 131 Saudi students, 130 had access to a $3 \mathrm{G}$ mobile phone network. Figure 2 shows that the majority of the Saudi students (119) 'always' and 'usually' carry their mobile phones with them and only 12 students only carry their phones with them 'sometimes'. Based on the answers to question 8, 130 students have access to resources using $3 \mathrm{G}$ mobile phone networks, which means that they are able to use their mobile phone as a tool to gain knowledge and information online.

TABLE I.

THE DESCRIPTION OF DEMOGRAPHIC INFORMATION OF THE STUDY SAMPLE

\begin{tabular}{|c|c|c|c|}
\hline & Gender & Age & Educational level \\
\hline Female & 42 & & \\
\hline Male & 89 & & \\
\hline $18-23$ & & 3 & \\
\hline $24-28$ & & 25 & \\
\hline $29-33$ & & 49 & \\
\hline $34-38$ & & 37 & \\
\hline $39-44$ & & 15 & \\
\hline $45+$ & & 2 & \\
\hline Bachelor & & & 14 \\
\hline Masters & & & 57 \\
\hline $\mathrm{PhD}$ & & & 58 \\
\hline Vocational Training & & & 1 \\
\hline $\begin{array}{l}\text { Professional Train- } \\
\text { ing }\end{array}$ & & & 1 \\
\hline Total & 131 & 131 & 131 \\
\hline
\end{tabular}

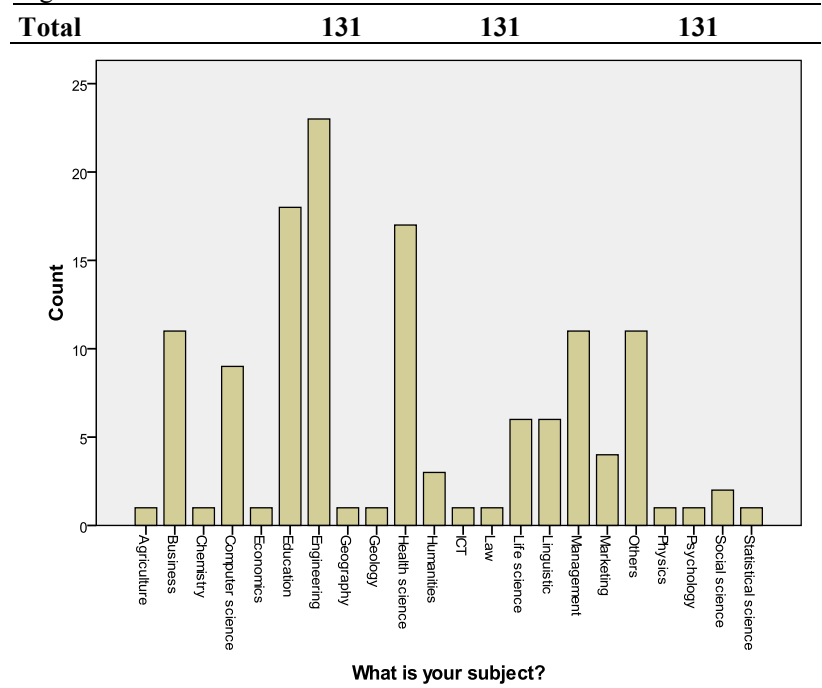

Figure 1. Subject distribution

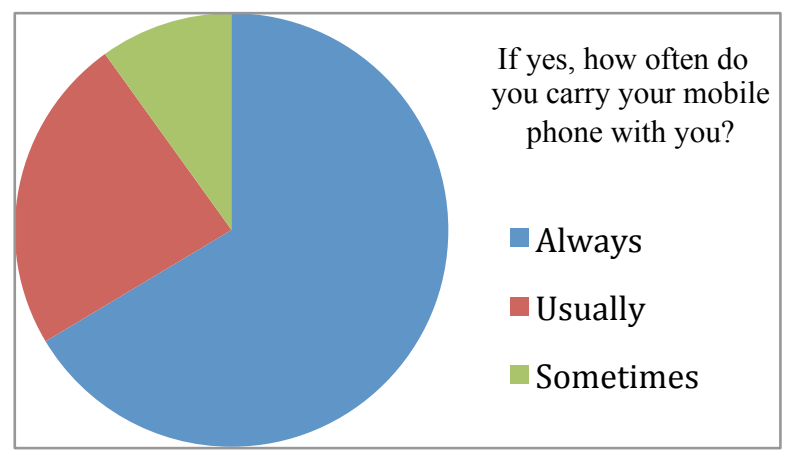

Figure 2. How often do you carry your mobile phone? 
Table II shows that the majority of participants 'always' or 'usually' uses mobile phones at home, at the workplace, at university and during leisure time. It is clear that Saudi students are used to using their mobile phones at university.

The table above illustrates how familiar the Saudi students are with using different applications on their mobile phones. It shows that students 'very often' use different mobile applications (such as SMS, email, social networks, etc.). This means that the students are accustomed to mobile phones and their applications. This fact is highly conducive to m-learning.

Table IV reveals that more than $87 \%$ of the students are using mobile phones for Internet browsing 'very often' or almost 'always'. This is of note as it shows that students are using mobile phones in the same way that they use a laptop computer and therefore they have the ability to use mobiles instead of a computer to support learning processes.

The information given in Table $\mathrm{V}$ indicates that Saudi students are willing to accept m-learning as a formal method for future study. The majority of the students 'strongly agree' or 'agree' that they like to use mobiles phones for learning and are confident about such use. 78\% of the participants believe that m-learning can provide new methods to acquire knowledge.

The level of understanding of m-learning from the Saudi students' perspective can be deduced from the results presented in Table VI. The majority of students agreed, or strongly agreed, that mobiles can be used to (1) read lectures from the university website using mobiles; (2) learning without a teacher; (3) listening to audio lectures; (4) reading e-books; (5) just-in-time learning; (6) knowledge/thought sharing; (7) learning and communicating at any time and from anywhere; and (8) an extension of e-learning.

The majority of the students who were surveyed are interested in owning a new mobile device with advanced features if this could improve their learning and performance at university. This is an important point, as mlearning requires the use of advanced mobile devices which can assist the learning process.

Table VII shows that the majority $(80 \%)$ of students believes that m-learning will increase the opportunities for learning and can save time. It shows that students think that m-learning is easy, as it is possible to learn, meet needs and interests and gain feedback from lecturers more quickly than through traditional methods. A unique feature of m-learning is that learning can occur when the learner is not in a fixed location, as can be seen in Table 7 with rates of use of handheld devices equalling $86 \%$ : hence m-learning can be used anytime and anywhere.

TABLE II.

WHERE DO YOU USE YOUR MOBILE PHONE MOST OFTEN?

\begin{tabular}{|l|c|c|c|c|c|}
\hline & Always & Usually & Sometimes & $\begin{array}{c}\text { Almost } \\
\text { Never }\end{array}$ & Never \\
\hline Home & $\begin{array}{c}87 \\
(66 \%)\end{array}$ & $\begin{array}{c}31 \\
(24 \%)\end{array}$ & $\begin{array}{c}12 \\
(9.2 \%)\end{array}$ & $\begin{array}{c}1 \\
(0.8 \%)\end{array}$ & 0 \\
\hline Work & $\begin{array}{c}46 \\
(35 \%)\end{array}$ & $\begin{array}{c}38 \\
(29 \%)\end{array}$ & $\begin{array}{c}42 \\
(32 \%)\end{array}$ & $\begin{array}{c}5 \\
(4 \%)\end{array}$ & 0 \\
\hline University & $\begin{array}{c}49 \\
(37 \%)\end{array}$ & $\begin{array}{c}38 \\
(29 \%)\end{array}$ & $\begin{array}{c}34 \\
(26 \%)\end{array}$ & $\begin{array}{c}10 \\
(8 \%)\end{array}$ & 0 \\
\hline Leisure & $\begin{array}{c}56 \\
(43 \%)\end{array}$ & $\begin{array}{c}31 \\
(23 \%)\end{array}$ & $\begin{array}{c}36 \\
(28 \%)\end{array}$ & $\begin{array}{c}8 \\
(6 \%)\end{array}$ & 0 \\
\hline
\end{tabular}

TABLE III.

WHERE DO YOU USE YOUR MOBILE PHONE MOST OFTEN?

\begin{tabular}{|l|c|c|c|c|}
\hline & $\begin{array}{c}\text { Very } \\
\text { Often }\end{array}$ & Sometimes & $\begin{array}{c}\text { Almost } \\
\text { Never }\end{array}$ & Never \\
\hline Call & $77.1 \%$ & $22.1 \%$ & $0.8 \%$ & 0 \\
\hline SMS/MMS & $37 \%$ & $50 \%$ & $13 \%$ & 0 \\
\hline Email & $63 \%$ & $31 \%$ & $6 \%$ & 0 \\
\hline Camera & $50 \%$ & $46 \%$ & $4 \%$ & 0 \\
\hline Entertainment & $29 \%$ & $39 \%$ & $32 \%$ & 0 \\
\hline Podcast & $38 \%$ & $38 \%$ & $14 \%$ & 0 \\
\hline Social Network & $72 \%$ & $21 \%$ & $7 \%$ & 0 \\
\hline Weather & $40 \%$ & $41 \%$ & $19 \%$ & 0 \\
\hline Reminder & $49 \%$ & $35 \%$ & $16 \%$ & 0 \\
\hline Translate & $45 \%$ & $39 \%$ & $16 \%$ & 0 \\
\hline Calendar & $57 \%$ & $36 \%$ & $7 \%$ & 0 \\
\hline
\end{tabular}

TABLE IV.

MOBILE PHONE USE AS AN INTERNET BROWSER

\begin{tabular}{|l|c|c|c|c|c|}
\hline & $\begin{array}{c}\text { Very } \\
\text { often }\end{array}$ & Always & $\begin{array}{c}\text { Some- } \\
\text { times }\end{array}$ & $\begin{array}{c}\text { Almost } \\
\text { never }\end{array}$ & never \\
\hline $\begin{array}{l}\text { I use my mobile } \\
\text { phone for Inter- } \\
\text { net browsing. }\end{array}$ & $\begin{array}{c}42 \\
(32 \%)\end{array}$ & $\begin{array}{c}70 \\
(54 \%)\end{array}$ & $\begin{array}{c}15 \\
(12 \%)\end{array}$ & $\begin{array}{c}2 \\
(1 \%)\end{array}$ & $\begin{array}{c}2 \\
(1 \%)\end{array}$ \\
\hline
\end{tabular}

TABLE V.

ACCEPTANCE OF M-LEARNING

\begin{tabular}{|l|c|}
\hline \multicolumn{1}{|c|}{ Statement } & $\begin{array}{c}\text { Positive } \\
\text { responses }\end{array}$ \\
\hline $\begin{array}{l}\text { I like to use my own mobile phone for my own } \\
\text { learning. }\end{array}$ & $\begin{array}{c}97 \\
(74 \%)\end{array}$ \\
\hline $\begin{array}{l}\text { I am confident when using my mobile phone for } \\
\text { learning. }\end{array}$ & $\begin{array}{c}90 \\
(69 \%)\end{array}$ \\
\hline M-learning will increase the quality of e-learning. & $\begin{array}{c}98 \\
(75 \%)\end{array}$ \\
\hline M-learning provides me with new methods to learn. & $\begin{array}{c}102 \\
(78 \%)\end{array}$ \\
\hline
\end{tabular}

TABLE VI.

M-LEARNING FROM THE SAUDI STUDENTS' PERSPECTIVE

\begin{tabular}{|l|c|c|c|c|c|}
\hline & $\begin{array}{c}\text { strongly } \\
\text { agree }\end{array}$ & agree & Not sure & disagree & $\begin{array}{c}\text { Strongly } \\
\text { disagree }\end{array}$ \\
\hline $\begin{array}{l}\text { Reading lectures } \\
\text { from the universi- } \\
\text { ty website }\end{array}$ & $\begin{array}{c}17 \\
(13 \%)\end{array}$ & $\begin{array}{c}66 \\
(51 \%)\end{array}$ & $\begin{array}{c}28 \\
(21 \%)\end{array}$ & $\begin{array}{c}17 \\
(12 \%)\end{array}$ & $\begin{array}{c}4 \\
(2 \%)\end{array}$ \\
\hline $\begin{array}{l}\text { Learning without } \\
\text { a teacher }\end{array}$ & $\begin{array}{c}17 \\
(13 \%)\end{array}$ & $\begin{array}{c}62 \\
(47 \%)\end{array}$ & $\begin{array}{c}41 \\
(32 \%)\end{array}$ & $\begin{array}{c}9 \\
(7 \%)\end{array}$ & $\begin{array}{c}2 \\
(1 \%)\end{array}$ \\
\hline $\begin{array}{l}\text { Listening to audio } \\
\text { lectures }\end{array}$ & $\begin{array}{c}32 \\
(24 \%)\end{array}$ & $\begin{array}{c}76 \\
(58 \%)\end{array}$ & $\begin{array}{c}20 \\
(16 \%)\end{array}$ & $\begin{array}{c}3 \\
(2 \%)\end{array}$ & 0 \\
\hline Reading e-books & $\begin{array}{c}33 \\
(26 \%)\end{array}$ & $\begin{array}{c}60 \\
(46 \%)\end{array}$ & $\begin{array}{c}29 \\
(22 \%)\end{array}$ & $\begin{array}{c}8 \\
(6 \%)\end{array}$ & 0 \\
\hline $\begin{array}{l}\text { Just-in-time } \\
\text { learning }\end{array}$ & $\begin{array}{c}19 \\
(15 \%)\end{array}$ & $\begin{array}{c}60 \\
(46 \%)\end{array}$ & $\begin{array}{c}45 \\
(3 \%)\end{array}$ & $\begin{array}{c}7 \\
(5 \%)\end{array}$ & 0 \\
\hline $\begin{array}{l}\text { Knowledge } \\
\text { thought sharing }\end{array}$ & $\begin{array}{c}36 \\
(28 \%)\end{array}$ & $\begin{array}{c}70 \\
(54 \%)\end{array}$ & $\begin{array}{c}19 \\
(14 \%)\end{array}$ & $\begin{array}{c}6 \\
(4 \%)\end{array}$ & 0 \\
\hline $\begin{array}{l}\text { Learning and } \\
\text { communicating at } \\
\text { any time and } \\
\text { from anywhere }\end{array}$ & $\begin{array}{c}66 \\
(50 \%)\end{array}$ & $\begin{array}{c}53 \\
(41 \%)\end{array}$ & $\begin{array}{c}10 \\
(8 \%)\end{array}$ & $\begin{array}{c}2 \\
(1 \%)\end{array}$ & 0 \\
\hline $\begin{array}{l}\text { An extension of } \\
\text { e-learning }\end{array}$ & $\begin{array}{c}43 \\
(33 \%)\end{array}$ & $\begin{array}{c}67 \\
(51 \%)\end{array}$ & $\begin{array}{c}17 \\
(13 \%)\end{array}$ & $\begin{array}{c}4 \\
(3 \%)\end{array}$ & 0 \\
\hline
\end{tabular}


TABLE VII

M-LEARNING OPPORTUNITIES

\begin{tabular}{|l|c|}
\hline \multicolumn{1}{|c|}{ Statement } & $\begin{array}{c}\text { Positive } \\
\text { responses }\end{array}$ \\
\hline M-learning will bring new opportunities for learning. & $\begin{array}{c}105 \\
(80 \%)\end{array}$ \\
\hline M-learning can save my time. & $\begin{array}{c}103 \\
(79 \%)\end{array}$ \\
\hline I find m-learning easy, as it is possible to learn what I & 96 \\
want. & $(73 \%)$ \\
\hline M-learning meets my needs and interests. & $\begin{array}{c}82 \\
(63 \%)\end{array}$ \\
\hline $\begin{array}{l}\text { M-learning enables me to get feedback from lecturers } \\
\text { more quickly than before. }\end{array}$ & $\begin{array}{c}78 \\
(60 \%)\end{array}$ \\
\hline $\begin{array}{l}\text { M-learning is more flexible than traditional learning; it } \\
\text { can be anytime and anywhere. }\end{array}$ & $\begin{array}{c}113 \\
(86 \%)\end{array}$ \\
\hline $\begin{array}{l}\text { It is possible to achieve personal educational aims } \\
\text { through m-learning. }\end{array}$ & $\begin{array}{c}82 \\
(63 \%)\end{array}$ \\
\hline
\end{tabular}

TABLE VIII.

APPLYING M-LEARNING ENVIRONMENT INSIDE THE CLASSROOM

\begin{tabular}{|l|c|c|c|c|c|}
\hline & $\begin{array}{c}\text { Very } \\
\text { often }\end{array}$ & Often & $\begin{array}{c}\text { Occa- } \\
\text { sionally }\end{array}$ & Seldom & Never \\
\hline Accessing resources & $\begin{array}{c}50 \\
(38 \%)\end{array}$ & $\begin{array}{c}46 \\
(35 \%)\end{array}$ & $\begin{array}{c}23 \\
(18 \%)\end{array}$ & $\begin{array}{c}4 \\
(3 \%)\end{array}$ & $\begin{array}{c}8 \\
(6 \%)\end{array}$ \\
\hline Taking notes & $\begin{array}{c}26 \\
(20 \%)\end{array}$ & $\begin{array}{c}42 \\
(32 \%)\end{array}$ & $\begin{array}{c}38 \\
(29 \%)\end{array}$ & $\begin{array}{c}14 \\
(11 \%)\end{array}$ & $\begin{array}{c}11 \\
(8 \%)\end{array}$ \\
\hline Translating & $\begin{array}{c}72 \\
(56 \%)\end{array}$ & $\begin{array}{c}41 \\
(32 \%)\end{array}$ & $\begin{array}{c}11 \\
(9 \%)\end{array}$ & $\begin{array}{c}3 \\
(3 \%)\end{array}$ & 0 \\
\hline Texting & $\begin{array}{c}26 \\
(20 \%)\end{array}$ & $\begin{array}{c}35 \\
(27 \%)\end{array}$ & $\begin{array}{c}42 \\
(32 \%)\end{array}$ & $\begin{array}{c}15 \\
(11 \%)\end{array}$ & $\begin{array}{c}13 \\
(10 \%)\end{array}$ \\
\hline $\begin{array}{l}\text { Asking and answering } \\
\text { questions }\end{array}$ & $\begin{array}{c}34 \\
(26 \%)\end{array}$ & $\begin{array}{c}29 \\
(22 \%)\end{array}$ & $\begin{array}{c}41 \\
(31 \%)\end{array}$ & $\begin{array}{c}11 \\
(9 \%)\end{array}$ & $\begin{array}{c}16 \\
(12 \%)\end{array}$ \\
\hline $\begin{array}{l}\text { Exchanging ideas and } \\
\text { information with } \\
\text { instructors and stu- } \\
\text { dents }\end{array}$ & $\begin{array}{c}33 \\
(25 \%)\end{array}$ & $\begin{array}{c}37 \\
(28 \%)\end{array}$ & $\begin{array}{c}35 \\
(26 \%)\end{array}$ & $\begin{array}{c}10 \\
(8 \%)\end{array}$ & $\begin{array}{c}16 \\
(13 \%)\end{array}$ \\
\hline
\end{tabular}

Table VIII shows that the notion of applying the mlearning environment inside the classroom is welcomed by Saudi students in higher education. It shows that a majority of students will 'very often' or 'often' use their mobiles to access resources, take notes, translate, text, ask and answer questions and exchange ideas and information with instructors and other students. As mentioned previously, the sample selected for this study comprises Saudi Arabian higher education students whose first language is Arabic and who are studying at UK universities. It is interesting that the percentage using mobile phones for translation in the classroom is $88 \%$, which demonstrates that Saudi students are already applying m-learning in their learning activities.

\section{CONCLUSION}

This paper has presented the findings of a pilot study exploring the possibility of integrating m-learning into Saudi Arabian higher education institutions. It has also presented m-learning and the unique opportunities it provides from the perspective of Saudi students. The analysis of their responses revealed that the students are ready to use mobile phones for their studies. They believe that it is possible to achieve personal educational aims through mlearning and that using mobile phones in the classroom would help to expedite their learning.
The participants pointed out that the use of mobile phones inside the classroom has positive outcomes in terms of increasing study skills and knowledge acquisition. Therefore, higher education policy makers should consider the possibility of creating an m-learning environment at Saudi Arabian academic institutions.

\section{FUTURE WORK}

Because of cultural and religious norms there is gender segregation in the higher education system in Saudi Arabia. In terms of access to educational systems unequal opportunities and challenges are expected to exist between male and female students. M-learning may offer opportunities to tackle this problem, providing equal opportunities and bridging the gaps between Saudi male and female students.

The future work for this research will focus on women's learning environment in Saudi universities. Mlearning can empower Saudi female students to overcome social and cultural obstacles and to claim their rights.

\section{REFERENCES}

[1] Ally, M. "State of Mobile Learning in Canada and Future

[2] Directions.' Athabasca University, 2011.

[3] O’Malley, C., Vavoula, G., Glew, J.P., Taylor, J., Sharples, M., \& Lefrere, P. "WP4 - Guidelines for learning/teaching/tutoring in a mobile environment" MOBIlearn deliverable. 2004, Available:

[4] http://www.mobilearn.org/download/results/guidelines.pdf

[5] International Telecommunication Union. Retrieved from:

[6] http://www.itu.int/net/pressoffice/press_releases/2014/23.aspx\#.U 5W8fvmwKkE

[7] Communication and Information. Retrieved from:

[8] http://www.citc.gov.sa/English/Reportsandstudies/Indicators/Page s/CITCICTIndicators.aspx

[9] Gasser, U. "What Companies Should Know About Digital Natives"' 2009. Retrieved from:

[10] http://www.web-strategist.com/blog/2009/05/14/what-companiesshouldknowabout-digital-natives/

[11] Sharples, M., Taylor, J., \& Vavoula, G. "A theory of learning for the mobile age." The Sage Handbook of Elearning Research. London: Sage, 2007.

[12] Altameem, T. "Contextual Mobile Learning System for Saudi Arabian Universities,' International Journal of Computer Applications, vol. 21, no. 4, pp. 21-26, May 2011. http://dx.doi.org/10.5120/2499-3377

[13] Al-Fahad, F. "Students' attitudes and perceptions towards the effectiveness of mobile learning in King Saud University, Saudi Arabia,' The Turkish Online Journal of Educational Technology - TOJET, vol. 8, no. 2, pp. 111-119, April 2009.

[14] F. Chanchary \& S. Islam. "Mobile learning in Saudi Arabia Prospects and challenges." The International Arab Conference on information Technology, Zarga University, Jordan, 2011.

[15] Pavan, A. "A new perspective on the quest for education: The Saudi Arabian way to knowledge society." Higher Education Studies, vol. 3, pp. 25-34, 2013. http://dx.doi.org/10.5539/ hes.v3n6p25

[16] Cohen, L., Manion, L. \& Morrison, K. "Research methods in education." 5 ed, Abingdon: Routledge, 2000. http://dx.doi.org/10.4324/9780203224342

\section{AUTHORS}

Sulaiman Almutairy, Trevor Davies, and Yota Dimitriadi are with the Institute of Education, University of Reading, United Kingdom (e-mail: s.m.s.almutairy@, pgr.reading.ac.uk, t.c.davies@reading.ac.uk, y.dimitriadi @)reading.ac.uk).

Submitted 28 January 2015. Published as resubmitted by the authors 18 May 2015. 